ORIGINAL ARTICLE

\title{
Abnormal cognitive function in treated congenital hypopituitarism
}

\author{
K Brown, J Rodgers, H Johnstone, W Adams, M Clarke, M Gibson, T Cheetham
}

Arch Dis Child 2004;89:827-830. doi: 10.1136/adc.2003.029116

See end of article for authors' affiliations ......................

Correspondence to: Dr T D Cheetham, Dept of Paediatrics, Royal Victoria Infirmary, Newcastle upon Tyne NE1 4LP, UK: t.d.cheetham@ncl.ac.uk

Accepted 28 January 2004

Aims: To assess cognitive function in school age children with congenital pituitary hormone deficiency (PHD).

Methods: Ten children with PHD (aged 6.0-15.6 years, mean 11.5 years) and sibling controls (aged 8.714.9 years, mean 12.1 years) were assessed using the Wechsler Intelligence Scale for Children (WISC-III UK).

Results: The patients' full scale IQ scores were all below average (mean 75, 95\% Cl 70-80), but were not significantly different to those of sibling controls (mean $82,95 \% \mathrm{Cl} 75-89$ ). There was no difference in verbal IQ between patients and siblings, but performance IQ was significantly reduced (mean 75, 95\% Cl 68-82 in patients; mean $88,95 \% \mathrm{Cl} 80-96$ in sibling controls). The reduced performance IQ reflected a poorer performance in tasks assessing perceptual organisational skills.

Conclusions: Data suggest that children with PHD have an IQ that is below average when compared to the population norm and a reduced performance IQ when compared to sibling controls. This may reflect abnormal brain development or could be linked to the impact of hypoglycaemia or low thyroxine concentrations in early life. This information is of value when counselling parents and planning a child's care and education, although further, more extensive studies of patients and siblings are required.

\footnotetext{
C
} hildren with congenital pituitary hormone deficiency (PHD) have quantitative and qualitative abnormalities of pituitary hormone production. Many have midline CNS abnormalities on magnetic resonance imaging (MRI) that can include an abnormal pituitary gland and/or hypothalamus, absent septum pellucidum, and optic nerve hypoplasia. This picture can be viewed as a spectrum of hormonal and associated midline abnormalities ranging from isolated growth hormone deficiency with normal MR images through to septo-optic dysplasia (absent septum pellucidum and optic nerve hypoplasia) with associated multiple pituitary hormone deficiency (MPHD). ${ }^{1-5}$

PHD is associated with significant morbidity that may be linked to the underlying hormone deficiency. Children are susceptible to hypoglycaemia in early life, prolonged neonatal jaundice, and short stature depending on whether they are adrenocorticotrophic hormone (ACTH), thyroid stimulating hormone (TSH), and/or growth hormone (GH) deficient. ${ }^{67}$

There is little objective data on the cognitive function of children with pituitary hormone deficiency and yet there are a number of reasons why this might be different to control subjects. Abnormal brain development as well as postnatal insults such as hypoglycaemia, hypothyroidism, and abnormal growth could all impact on the normal developmental process. We have therefore undertaken a preliminary study to assess cognitive skills in this group of patients in comparison to sibling controls.

\section{PATIENTS AND METHODS}

\section{Study design}

This was a cross sectional study involving the assessment of cognitive function in school age children diagnosed with congenital hypopituitarism attending the tertiary paediatric endocrine clinic at the Royal Victoria Infirmary in Newcastle upon Tyne. The same assessment of cognitive function was performed in a sibling control. In all but two families there was only one sibling; in the remaining two families the sibling with an age closest to the patient was selected. Ethical approval for the study was granted by the local joint ethics committee. Patients were included if they had MPHD or if they had isolated GH deficiency together with a documented abnormal pituitary gland and/or hypothalamus on cranial MRI. Patients were excluded if there were other potential cognitive impairing factors.

\section{Methods}

Cognitive function was assessed by a psychologist using the Wechsler Intelligence Scale for Children (WISC-III UK). ${ }^{8}$ The WISC-R consists of 13 sub-tests, each measuring a different facet of intelligence. The child's attainments on these various measures are summarised into three composite scores, the verbal, performance, and full scale IQs, which provide estimates of the individual's intellectual ability. In addition the WISC-III UK provides four optional factor based index scores (perceptual organisation, freedom from distractibility, processing speed and verbal comprehension) allowing a more detailed examination of the strengths and weaknesses of an individual's performance. Based on the UK normative data and in line with the IQ scores the Index Scores have a mean of 100 and standard deviation of 15. Assessment is performed on an individual basis and takes approximately 60 minutes to complete.

All patients underwent an ophthalmological assessment, including fundoscopy and an assessment of visual acuity.

\section{Study population}

Ten children with PHD and their families consented to take part in the study. All were stable on a hormone replacement regimen that included a daily injection of recombinant human GH. Patients on thyroxine replacement were biochemically euthyroid (normal free thyroxine concentrations); patients with secondary hypoadrenalism were on a twice or three times daily hydrocortisone regimen. The patients' ages ranged from 6.0 to 15.6 years (mean 11.5 years) and the siblings from 8.7 to 14.9 years (mean 12.1 years). All the siblings were well and did not have hypopituitarism.

\footnotetext{
Abbreviations: $A C T H$, adrenocorticotrophic hormone; $\mathrm{GH}$, growth hormone; MRI, magnetic resonance imaging; MPHD, multiple pituitary hormone deficiency; PHD, pituitary hormone deficiency; TSH, thyroid stimulating hormone; WISC, Wechsler Intelligence Scale for Children
} 
Of the 10 children with pituitary hormone deficiency, eight had MPHD and two had isolated GH deficiency with an abnormal cranial MRI (non-descended posterior pituitary bright spot). Details of the history leading up to the diagnosis as well as information about visual acuity were obtained from the hospital medical records. Table 1 summarises the patient characteristics.

The comparison of patient and sibling scores was undertaken using non-parametric statistical tests (Mann-Whitney U test).

\section{RESULTS}

The patients mean full scale IQ score of 75 (range 66-88, 95\% CI 70-80) was in the low range when compared to the population norm. The sibling controls had a mean IQ score of 82 (range 68-105, 95\% CI 75-89) in the low average range, although their scores were not significantly different from those of the patients $(p=0.1)$. Patients however, had a significantly lower performance IQ score when compared to sibling controls (mean 75, range 64-99, 95\% CI 68-82 in patients; mean 88 , range $73-112$, 95\% CI 80-96 in siblings; $\mathrm{p}=0.02$ ). There was no significant difference between the two groups with respect to verbal IQ (mean 77, range 55-98, $95 \%$ CI $70-84$ in patients; mean 82 , range $73-100$, 95\% CI 7589 in siblings; $\mathrm{p}=0.2$ ).

Analysis of the 10 sibling pairs with respect to the four index scores revealed that the patients were presenting with significantly lower scores for perceptual organisation (mean $75,95 \%$ CI $68-82$ versus $89,95 \%$ CI $83-95 ; p=0.009)$. There were no significant differences in performance between the patients and sibling controls on the three remaining index scores (table 2).

\section{DISCUSSION}

The principle findings of our study are that children with pituitary hormone deficiency have an intellectual ability that is within the lower than average range when compared to the
Table 2 Means and ranges for the four index scores from the WISC-III UK

\begin{tabular}{|c|c|c|c|}
\hline Measure & $\begin{array}{l}\text { Patients } \\
\text { Mean } \\
\text { (range) } \\
{[95 \% \mathrm{Cl}]}\end{array}$ & $\begin{array}{l}\text { Siblings } \\
\text { Mean } \\
\text { (range) } \\
{[95 \% \mathrm{Cl}]}\end{array}$ & $p$ value \\
\hline Perceptual organisation & $\begin{array}{l}75 \\
(64-98) \\
{[68-82]}\end{array}$ & $\begin{array}{l}89 \\
(74-104) \\
{[83-95]}\end{array}$ & 0.009 \\
\hline Processing speed & $\begin{array}{l}87 \\
(68-112) \\
{[78-96]}\end{array}$ & $\begin{array}{l}97 \\
(73-137) \\
{[86-108]}\end{array}$ & 0.24 \\
\hline Verbal comprehension & $\begin{array}{l}75 \\
(56-91) \\
{[68-82]}\end{array}$ & $\begin{array}{l}81 \\
(64-97) \\
{[74-88]}\end{array}$ & 0.24 \\
\hline Freedom from distractibility & $\begin{array}{l}92 \\
(71-106) \\
{[84-100]}\end{array}$ & $\begin{array}{l}94 \\
(77-109) \\
{[87-101]}\end{array}$ & 0.74 \\
\hline
\end{tabular}

population norm and a low performance IQ when compared to their siblings. The reduced performance IQ in comparison to sibling controls could be accounted for primarily by a patient's reduced ability to perform tasks involving perceptual organisational skills.

The tasks comprising the perceptual organisation index are picture completion, picture arrangement, block design, and object assembly. Processing speed, consisting of coding, and symbol search sub-tests did not differ between patients and controls. The tasks comprising the perceptual organisation index involve the interpretation and organisation of visually presented information, whereas the sub-tests of processing speed require the child to copy or transcribe visual material in a time limited test. The fact that the PHD children were not under-performing compared to their siblings on the processing speed tasks suggests that visual acuity was not influencing test performance and hence it is higher order visual

Table 1 Patient characteristics

\begin{tabular}{|c|c|c|c|c|c|c|}
\hline Patient & Age at assessment & Gender & Visual acuity & Cranial MRI scan & Major presenting feature(s) & $\begin{array}{l}\text { Known hormone } \\
\text { deficiencies + age at GH } \\
\text { therapy }\end{array}$ \\
\hline 1 & $9.8 y$ & $M$ & $\begin{array}{l}6 / 15,6 / 9.5 \\
\text { Nystagmus } \\
\text { Normal discs }\end{array}$ & Not done & $\begin{array}{l}\text { Hypoglycaemia + } \\
\text { small phallus }\end{array}$ & $\begin{array}{l}\text { GH, TSH, ACTH } \\
\text { Gn (micropenis) } \\
\text { GH } 0.9 y\end{array}$ \\
\hline 2 & $6.0 y$ & M & $\begin{array}{l}6 / 9.5,6 / 9.5 \\
\text { Normal discs }\end{array}$ & Not done & $\begin{array}{l}\text { Family history of PHD + } \\
\text { hypoglycaemia }\end{array}$ & $\begin{array}{l}\text { GH, TSH, ACTH } \\
\text { Gn (micropenis) } \\
\text { GH } 0.9 \text { y }\end{array}$ \\
\hline 3 & $6.2 y$ & $\mathrm{~F}$ & $\begin{array}{l}6 / 6,6 / 9.5 \\
\text { Normal discs }\end{array}$ & Pituitary aplasia & Hypoglycaemia + short stature & $\begin{array}{l}\text { GH, TSH, ACTH } \\
\text { GH } 1.1 \text { y }\end{array}$ \\
\hline 4 & $13.9 y$ & $\mathrm{~F}$ & $\begin{array}{l}6 / 12,6 / 12 \\
\text { Normal discs }\end{array}$ & $\begin{array}{l}\text { Pituitary hypoplasia } \\
\text { NDPP }\end{array}$ & Hypoglycaemia & $\begin{array}{l}\mathrm{GH}, \mathrm{TSH}, \mathrm{ACTH} \\
\mathrm{Gn} \text { (late puberty) } \\
\mathrm{GH} 12.2 \mathrm{y}\end{array}$ \\
\hline 5 & $6.0 y$ & $\mathrm{~F}$ & $\begin{array}{l}6 / 6,6 / 6 \\
\text { Normal discs }\end{array}$ & $\begin{array}{l}\text { Absent stalk } \\
\text { NDPP }\end{array}$ & $\begin{array}{l}\text { Hypoglycaemia } \\
\text { Jaundice }\end{array}$ & $\begin{array}{l}\text { GH, TSH, ACTH } \\
\text { GH } 1.1 \text { y }\end{array}$ \\
\hline 6 & $12.2 y$ & M & $\begin{array}{l}6 / 12,6 / 60 \\
\text { Optic nerve } \\
\text { hypoplasia }\end{array}$ & $\begin{array}{l}\text { Pituitary hypoplasia } \\
\text { Absent PPBS }\end{array}$ & Hypoglycaemia & $\begin{array}{l}\text { GH, TSH, ACTH } \\
\text { Gn (micropenis) } \\
\text { GH } 6.7 y\end{array}$ \\
\hline 7 & $8.2 y$ & M & $\begin{array}{l}6 / 9,6 / 9 \\
\text { Normal discs }\end{array}$ & $\begin{array}{l}\text { Pituitary hypoplasia } \\
\text { NDPP }\end{array}$ & Hypoglycaemia & $\begin{array}{l}\text { GH, TSH, ACTH } \\
\text { Gn (micropenis) } \\
\text { GH } 1.4 y\end{array}$ \\
\hline 8 & $15.6 y$ & M & $\begin{array}{l}6 / 5,6 / 5 \\
\text { Normal discs }\end{array}$ & $\begin{array}{l}\text { Pituitary hypoplasia } \\
\text { Absent stalk } \\
\text { NDPP }\end{array}$ & Short stature & $\begin{array}{l}\mathrm{GH} \\
\mathrm{GH} 5.2 y\end{array}$ \\
\hline 9 & $8.8 y$ & $M$ & $\begin{array}{l}6 / 6,6 / 6 \\
\text { Normal discs }\end{array}$ & $\begin{array}{l}\text { Pituitary hypoplasia } \\
\text { Absent stalk } \\
\text { NDPP }\end{array}$ & Short stature & $\begin{array}{l}\mathrm{GH} \\
\mathrm{GH} 6.0 y\end{array}$ \\
\hline 10 & $7.0 y$ & $\mathrm{~F}$ & $\begin{array}{l}5 / 60,2 / 60 \\
\text { Optic nerve } \\
\text { hypoplasia }\end{array}$ & $\begin{array}{l}\text { Optic nerve } \\
\text { hypoplasia }\end{array}$ & $\begin{array}{l}\text { Slow growth } \\
\text { Optic nerve hypoplasia }\end{array}$ & $\begin{array}{l}\mathrm{GH} \\
\mathrm{GH} 5.7 y\end{array}$ \\
\hline
\end{tabular}


processing which is likely to be impaired. This is very important from an educational perspective and may guide the way in which material is presented to the child in the classroom.

Abnormalities of visual-motor integration among patients with hypopituitarism have been described previously. ${ }^{9}$ A range of assessments, including the WISC, were used in this study, with the authors concluding that overall performance was in the low-average range. A link between academic performance and socioeconomic status was identified, but siblings were not used as a control group.

There are a number of possible explanations for the discrepancy that we have identified between children with PHD, their siblings, and the population norm. Our understanding of the aetiology of PHD has advanced considerably in recent years, and a small but expanding number of genes are known to be important in the development of midline structures. Studies of a blind child with septo-optic dysplasia identified a specific spatial learning defect when compared to a blind control child, ${ }^{10}$ and our observations could be linked to the abnormal development of midline structures. Abnormalities of brain development in PHD can also include structures other than those in the midline, and impaired perceptual organisational skills may be a manifestation of impaired visual processing in an abnormally developed brain.

The production of GH is affected most frequently in PHD; all our patients were GH deficient. They commenced GH therapy at a mean age of 49 months (range 10-147 months), and so there was a period in early life when these children had low circulating GH concentrations. Abnormal GH production has been associated with altered brain growth, and it could be argued that GH deficiency contributed to the differences that we identified. ${ }^{11}$ However, a recent study of individuals with GH insensitivity syndrome did not show any difference in performance when compared to controls. ${ }^{12}$ All our patients were receiving appropriate GH replacement at the time of the study.

It has been suggested that abnormal perceptual-motor skills in adults with MPHD could be linked to a deficiency of pituitary hormones besides GH. ${ }^{13}$ Children with PHD, and particularly those with ACTH deficiency, are susceptible to hypoglycaemia, which is a well recognised cause of neurocognitive dysfunction. ${ }^{14}{ }^{15}$ Most of our subjects had a history of hypoglycaemia in early life, and altered glucose homoeostasis may have contributed to the discrepancy between patients and siblings that we observed. Severe hypoglycaemia may preferentially harm neurones in the medial-temporal region, specifically the hippocampus, ${ }^{16}{ }^{17}$ and a reduction in performance across a broad range of neuropsychological tests has been reported in children with diabetes who have a history of severe hypoglycaemia. Patients with PHD are susceptible to hypoglycaemia in infancy but may have alternative fuel sources when compared to patients with diabetes who are hyperinsulinaemic. It is therefore likely that the impact of hypoglycaemia is different in PHD patients.

Patients with hypopituitarism may still be susceptible to hypoglycaemia on standard replacement therapy when they are well. ${ }^{18}$ Adults show signs of cognitive impairment by the time blood glucose concentrations fall to $2.6 \mathrm{mmol} / \mathrm{l}$, with impaired attention, discrimination, and motor speed reaction, mental tracking, ability to inhibit conflicting inputs, and short term memory recall. ${ }^{19}{ }^{20}$ A study conducted in children with diabetes has shown a significant decline in mental efficiency at blood glucose concentrations of 3.3-3.6 mmol/l, which was most apparent on measures requiring planning and decision making. ${ }^{21}$ Performance could theoretically be affected by recent alterations in blood glucose concentrations, and while our patients were not fasting at the time of testing, this possibility cannot be completely discounted.
Most of the patients we studied had secondary hypothyroidism and may have had relatively low thyroxine concentrations at the critical phase of CNS growth in early life. The thyroxine dose used to treat infants with congenital hypothyroidism can influence IQ and behaviour, and so it is possible that low or low normal thyroxine levels in patients with hypopituitarism can influence the child's subsequent neurodevelopment. ${ }^{22}$

PHD is a heterogeneous disorder in terms of aetiology and severity. PHD is uncommon and our study is limited by the size of the patient group and sibling controls. Sibling controls had a relatively low IQ, and the fact that full scale IQ was not significantly different to that of the patients could be linked to the small study population. Educational attainments of parents were not recorded, but genetic factors as well as social class could provide some explanation for the below average IQ in patients and siblings. It is also theoretically possible that living in a family with a PHD child could have an impact on ability. Larger, collaborative studies of IQ in these patients with sibling and unrelated controls which will help to address the possibility of type 1 and type 2 statistical error in our results are therefore needed. Patients and siblings need to be tested "blind", and studies should focus on hormone deficiency (for example, GH deficiency versus GH and TSH deficiency), MR imaging, as well as the analysis of the genes known to be involved in pituitary development.

In summary, our data suggest that children with congenital PHD have lower than average cognitive function but a specific difficulty with perceptual organisation when compared to siblings. This may be linked to illnesses such as hypoglycaemia in early life, thyroxine deficiency, or be a manifestation of abnormal central nervous system development.

\section{ACKNOWLEDGEMENTS}

We would like to acknowledge Dr Tom Kelly for his help with the data analysis.

\section{Authors' affiliations}

K Brown, H Johnstone, M Gibson, T Cheetham, Department of Paediatrics, Royal Victoria Infirmary, Newcastle upon Tyne, UK W Adams, M Clarke, Department of Ophthalmology, Royal Victoria Infirmary, Newcastle upon Tyne, UK

J Rodgers, Department of Clinical Psychology, University of Newcastle upon Tyne, UK

\section{REFERENCES}

1 Traggiai C, Stanhope R. Endocrinopathies associated with midline cerebral and cranial malformations. J Pediatr 2002;140:252-5.

2 Thomas PQ, Dattani MT, Brickman JM, et al. Heterozygous HESXI mutations associated with isolated congenital pituitary hypoplasia and septo-optic dysplasia. Hum Mol Gen 2001;10:39-45.

3 Dattani MT, Robinson IC. The molecular basis for developmental disorders of the pituitary gland in man. Clin Genet 2000;57:337-46.

4 Hellstrom A, Aronsson M, Axelson C, et al. Children with septo-opticdysplasia-how to improve and sharpen the diagnosis. Horm Res 2000;53(suppl 1):19-25.

5 Dattani MT, Martinez-Barbera JP, Thomas PQ, et al. Mutations in the homeobox gene HESX1/Hesxl associated with septo-optic dysplasia in human and mouse. Nat Genet 1998;19:125-33.

6 Kaufman FR, Costin G, Thomas DW. Neonatal cholestasis and hypopituitarism. Arch Dis Child 1984;59:787-9.

7 Lovinger RD, Kaplan SL, Grumbach MM. Congenital hypopituitarism associated with hypopituitarism and microphallus: four cases secondary to hypothalamic hormone deficiencies. J Pediatr 1975;87:1171-81.

8 Weschler D. Weschler Intelligence Scale for Children-Revised. New York: The Psychological Corporation, 1974.

9 Abbott D, Rotnem D, Genel M, et al. Cognitive and emotional functioning in hypopituitary short-statured children. Schizophr Bull 1982;8:310-19.

10 Griffiths P, Hunt S. Specific spatial defect in a child with septo-optic dysplasia. Dev Med Child Neurol 1984;26:395-400.

11 Laron Z, Galatzer A. Growth hormone, somatomedin and prolactinrelationship to brain function. Brain Dev 1985;7:559-67.

12 Kranzler JH, Rosenbloom AL, Martinez V, et al. Normal intelligence with severe insulin-like growth factor I deficiency due to growth hormone receptor deficiency: a controlled study in a genetically homogeneous population. J Clin Endocrinol Metab 1998;83:1953-8. 
13 Deijen JB, De Boer H, Blok GJ, et al. Cognitive impairments and mood disturbances in growth hormone deficient men. Psychoneuroendocrinology 1996;21:313-22.

14 Menni F, de Lonlay P, Sevin C, et al. Neurologic outcomes of 90 neonates and infants with persistent hyperinsulinemic hypoglycemia. Pediatrics 2001; 107:476-9

15 Lucas A, Morley R, Cole TJ. Adverse neurodevelopmental outcome of moderate neonatal hypoglycaemia. BMJ 1988;297:1304-8.

16 Auer RN, Hugh J, Cosgrove EC, et al. Neuropathological findings in three cases of profound hypoglycaemia. Clin Neuropathol 1989;8:63-8.

17 Auer RN, Olsson Y, Siesjo BK. Hypoglycaemic brain injury in the rat: correlation of density of brain damage with the EEG iso-electric time: a quantitative study. Diabetes 1984;33:1090-8.
18 Houdijk EC, Herdes E, Delemarre-Van de Waal HA. Pharmacokinetics and pharmacodynamics of recombinant human growth hormone by subcutaneous jet- or needle-injection in patients with growth hormone deficiency. Acta Paediatr 1997:86:1301-7.

19 Evans ML, Pernet A, Lomas J, et al. Delay in onset of awareness of acute hypoglycaemia and restoration of cognitive performance during recovery. Diabetes Care 2000;23:893-7.

20 Fruehwald-Schultes B, Born J, Kern W, et al. Adaptation of cognitive function to hypoglycaemia in healthy men. Diabetes Care 2000;23:1059-66.

21 Ryan CM, Atchison J, Puczynski M, et al. Mild hypoglycaemia associated with deterioration of mental efficiency in children with insulin-dependant diabetes mellitus. J Pediatr 1990;117:32-8.

22 Hindmarsh PC. Optimisation of thyroxine dose in congenital hypothyroidism. Arch Dis Child 2002;86:73-5.

\section{NOTES FROM AUSTRALIA}

\section{The early childhood agenda in Australia}

C hild advocacy is a complex, often frustrating, and never ending process. One of the key ingredients of successful advocacy is to understand and take advantage of local issues that capture the imagination of the public or the media, and capitalise on this interest to influence public policy.

It is interesting to look at examples of how this has been done in different countries. In North America, much of the momentum that has developed in early childhood policy has stemmed from what might loosely be called "brain development research". This is a mixture of old and new research showing that the first three years are especially important in influencing a child's long term functioning. It has been suggested that the rapidly developing brain in the first three years is extremely vulnerable to environmental influences, both positive and negative. Long term physiological functioning of the brain is affected by subtle structural changes influenced by these environmental experiences. Hertzmann has called the young child's brain "an environmental organ", which captures beautifully the profound influence the environment has in those early years.

The huge interest in early childhood and brain functioning has been given great impetus by a series of influential reports and publications from foundations and institutions such as the Carnegie Corporation, the Families and Work Institute, and the Rand Corporation. This has captured the interest of the mainstream media as well as parents and parent organisations. In most states in the USA there are policy initiatives addressing various early childhood issues. Similarly, in Canada there has been a significant push in recent years, both at a federal and provincial level, to increase the investment in services for young children and their families (www. childcarecanada.org/policy/polstudies/can/ earlyyrs.html).

In the UK, it seems that the drivers have been different. Sure Start, an innovative, community based programme designed to address poverty and its consequences in children under the age of 4, has generated a great deal of interest internationally, and is held up as a model whole-of-government approach to early childhood. Other drivers include enquiries and subsequent reports into the tragic deaths of children because of child abuse or failures in clinical quality systems, and an influential publication in the British Medical Journal several years ago, ${ }^{1}$ the outcome of which was the establishment of a children's task force.

In Australia too, early childhood is beginning to appear on the lips of politicians and policy makers. Most states in Australia now have some sort of policy initiative in early childhood. In New South Wales it is Families First, in Victoria Best Start, in South Australia "Every chance for every child: a healthy start for our children", in Tasmania "Our kids' action plan", and so on. While there are similarities in the content of the rhetoric used, there is considerable variability in the detail and the comprehensiveness of the programmes themselves, and by and large the additional investment in children's services has been paltry.

At national level too, the Liberal Government last year released a "National Agenda for Early Childhood" (www.facs.gov.au/internet/facsinternet. nsf/family/early_childhood.htm) as a discussion paper and invited comments and feedback, and engaged in a comprehensive consultation strategy with states and institutions. This has generated a positive response, and submissions regarding new policies (and more importantly money attached to them) are about to go to cabinet for endorsement.

The drivers of putting early childhood on the agenda have been different in Australia. The media has, until very recently, not been involved at all. Child abuse has intermittently been in the news, but this is largely a state issue so there have not been the national enquiries with far reaching recommendations as there have been in the UK.
The advocates for early childhood in Australia have been a passionate and committed group of professionals, with paediatricians prominent among them, who began lobbying and organising several years ago. An advocacy and information sharing group called the National Investment for the Early Years (NIFTeY; www.niftey.cyh.com) was established following a meeting of interested individuals held in 1999. More recently members of this group, again with paediatricians prominent, were involved in the establishment of the Australian Research Alliance for Children and Youth (ARACY; www.aracy.org.au). This is a national collaboration of researchers, policymakers, and practitioners from a broad range of disciplines, and has an ambitious agenda of establishing data networks, promoting collaborative research, and developing an effective communication and advocacy strategy.

The cause was helped greatly when the head of ARACY, Professor Fiona Stanley, herself a prominent child health researcher, was nominated as "Australian of the Year" for 2003. This gave her an influential and very public pulpit from which she could (and did) spread the message about the importance of the early years.

Finally, the election to the leadership of the federal opposition labour party of a youngish (early 40s) man-Mark Latham - who is himself the father of two young children, may well turn out to be the most effective policy lever of all. He has already flagged that early childhood will be a major policy plank for his party in the lead up to the next election, which must be held some time this year. Stay tuned.

Frank Oberklaid Centre for Community Child Health, Royal Children's Hospital Melbourne, Flemington Road, Parkville, Victoria 3052, Australia; frank.oberklaid@rch.org.au

\section{Reference}

1 Aynsley-Green A, Barker M, Burr S, et al. Who is speaking for children and adolescents and for their health at the policy level? BMJ 2000;321:229-32 